will be provided and the institute will act as a focus for interdisciplinary co-operation in the field of African studies for members of faculty and post-graduate students, with interdisciplinary seminars and a series of public lectures by distinguished visiting Africanists. The Institute has held a joint seminar with the University of California at Berkeley on the topic 'Africa in the wider world: the interrelationship of area and comparative studies' (June I966: see also Africa, xxxvi, April 1966, p. 204). It is also sponsoring an 'oral traditions project' covering Sierra Leone. It is intended that the Institute shall act as a centre for visiting scholars in the field of African studies and at the present time some eight visting research workers are using it as a base. Work has begun on the Institute building and it is estimated that it will be completed early in 1967 . The cost of $£ 40,000$ is being met by equal grants from the College and the United Kingdom Technical Assistance Programme.

The Director of the Institute is Mr. Michael Crowder and the Secretary Mr. J. G. Edowu Hyde.

\title{
British Institute of History and Archaeology in East Africa
}

Address: P.O. Box 7680, Nairobi. Director-H. N. Chittick.

THE Institute is concerned with research into the history and archaeology of East Africa and offers a number of Research Studentships for which graduates from Commonwealth countries are eligible.

The main field research activity has been the Director's excavations at Kilwa Kisiwani, formerly the greatest of the trading cities of the East African coast. These were completed in 1965 and are now being prepared for publication. Interim reports have been published in the Institute's Annual Report and in the Journal of African History. The Assistant Director, Robert Soper, is engaged on an archaeological survey of eastern Kenya and northern Tanzania with special emphasis on the Iron Age. This will continue for another year at least and reports will be published from time to time. Dr. Brian Fagan is directing a three-year research campaign, financed by the Astor Foundation, on the origins of the Bantu in eastern Africa, of which the first year is almost completed. Miss Alison Redmayne is studying the history of Uhehe and neighbouring areas on a research grant from the Institute.

The Institute's publications include the Annual Reports, from 1962 to date, and its journal Azania (see Africa, xxxv, July 1965, pp. 32 I-2). Publications in the press (Oxford University Press) are Prelude to East African History, ed. M. Posnansky; Early Islamic Architecture of the East African Coast, by P. S.Garlake; Land Policy, Legislation and Settlement in the East African Protectorate, by M. P. K. Sorrenson; and The Later Prehistory of the Western Highlands of Kenya, by J. E. G. Sutton.

\section{African Studies in Spain}

Spanish interest in African studies dates from the end of the last century, with the founding of such institutions as the Real Sociedad Geográfica and the Liga Africanista Española. From I920 to 1940 African activities declined, but between I940 and 1946 a number of Spanish scholars, notably the members of the Sociedad de Estudios Internacionales y Coloniales, worked for the revival of Spanish African studies, with the effective assistance of the Instituto de Estudios Políticos, and the Instituto de Estudios Africanos was created. The period 1960-I which brought the autonomy of the Equatorial Region (the former Spanish Guinea) was marked by increased interest in Africa and in the number of publications on it, and the establishment of diplomatic relations between Spain and the new African states. At present it is felt that Spain's experience in economic and social development may well be of assistance to these states, and it has been considered useful to list the 